IJ§ER

ISSN: 2149-5939
International Journal of Social Sciences and Education Research

Online, https://dergipark.org.tr/tr/pub/ijsser

Volume: 6(2), 2020

Research Article

\title{
Distance education and young learners of English during curfew period due to coronavirus pandemic
}

\author{
Zeynep Canl1 ${ }^{1}$ and Bekir Canl1 ${ }^{2}$
}

Received date: 17 / 05 / 2020

Accepted date: 30 / $06 / 2020$

\begin{abstract}
The aim of the study is to search online resources and materials which young learners of English use during the curfew period and what kind of education system young learners of English prefer; face to face education or distance education and to find out their reasons for their choices. The participants include 32 primary school students. Data were collected via semi-structured interviews by the help of Zoom meeting program. It was seen that all of the participants tried to use online resources and materials to improve their English during the difficult days spending at home because of COVID-19 pandemic. 30 participants preferred face to face education. However, two participants preferred distance education. The study may provide data for parents, teachers and authorities to encourage students' participation into learning activities in English during the curfew period of COVID-19 pandemic.
\end{abstract}

Keywords: Young learners of English, COVID-19 pandemic, online resources

\section{Introduction}

People have faced diseases all over the world and during their history. Epidemics have been among the worst diseases which people feel hopeless and stressed when they come across as Tutku, Ilıman and Dönmez (2020) aver that people have been affected relatively in every area of their daily lives such as health organizations, social interactions, educational accomplishments, etc. Since December 2019, every country and even every region in the world have been struggled against Coronavirus epidemic. The past seven-month process of Coronavirus pandemic shows that it has obtained an ineluctable rise in cases of both death and affected people. Furthermore, the study of Liu, Liu and Zhong (2020) supports the idea that the increase and spread of the Coronavirus pandemic have affected people either psychologically or sociologically, so its results may lead some adjustments in daily routines, every organizations and institutions in daily life. Countries try to get precautions against COVID-19 pandemic as curfew process, in this sense, people need to change and rearrange their habits and relationships in such situations. It can be said that children are affected by the results of the pandemic as everyone is affected (Kanbur \& Akgüt, 2020). As a result of the pandemic, distance education has gained importance for providing the continuum of the learning and teaching for primary school students because distance education has become a new meaning for both teachers and young learners of English in Turkey. Young learners have been accustomed to learn through the system of face to face education so far. The novel education system has been required to a smooth adaptation by all components of

${ }^{1}$ Kahramanmaraş Sütçü İmam University, Kahramanmaraş, zeyneppolat1312@,hotmail.com ORCID ID: https://orcid.org/0000-0002-1285-3364

${ }^{2}$ Ph.D. Kahramanmaraş Sütçü İmam University, Kahramanmaraş, bekircanli@,ksu.edu.tr ORCID ID: https://orcid.org/0000-0001-6648-4691 
Canl1, Z, Canl1, B. (2020). Distance education and young learners of English during curfew period due to coronavirus pandemic. International Journal of Social Sciences and Education Research, 6(2), 241-251.

the education especially children. Consequently, this study aims to search the changes of learning habits of young learners of English during curfew period due to COVID-19 and use of online resources and materials and their perceptions towards the distance education because of COVID19. The results of the study might be beneficial for educators, teachers of young learners of English, and parents who want to consider the current situations of young learners of English during COVID-19 curfew period and the perceptions of young learners of English towards distance education.

\section{Literature review}

\subsection{Distance education}

The term of distance education can be described by Uşun (2006, p.16) as "It is an educational technology that provides flexibility in terms of location, time, to the individual who receives education, provides individual and independent learning, and does not require the obligatory for the resource and receiver to be in the same place". Similarly, İşman (2008) supports that "communication technologies have been developing at an incredible speed. It can be assumed that these developments may affect the education system, too. One of these effects is distance education, which will be the education model of the 21 st century" (p.V). Hence, it may provide the expected opportunities in education during such serious and difficult time as COVID-19 pandemic period. Students at MoNE has stopped to continue their learning at schools and attended their lessons on EBA TV channels and Eba website as a part of distance education since March 16, 2020. Some teachers have shared and taught lessons via ZOOM application or Whatsapp. Some teachers have sent YouTube videos or suggested YouTube channels for their students to keep them active and motivated in the stressful period of curfew. Beside of TV channels, web 2.0 tools have taken place in students' every day and influenced their educational habits as "media has always had a direct impact on children's psychological, social, and cultural development” (Imaniah, Dewi \& Zakky, 2020, p.21).

On the other hand, it is assumed that distance education provides important opportunities in many ways. Obviously, Kaya (2002) claims that there are benefits of distance education as follows:

- Offering different education options to the students

- Minimize inequality of opportunities

- Facilitating mass education

- Providing standards in educational programs

- Reducing the cost in education

- Improving the quality of education

- Providing student freedom

- Offering a rich educational environment to the students

- Not to force the students to study in the classroom

- Providing individual learning

- Providing independent learning

- Gaining responsibility for learning to the individual

- Providing information from the first source

- Making more students benefit from the experienced teachers (p.19). 
Canl1, Z., Canl1, B. (2020). Distance education and young learners of English during curfew period due to coronavirus pandemic. International Journal of Social Sciences and Education Research, 6(2), 241-251.

By the help of the distance education, students can benefit from education opportunities of learning from different countries of the world. Global communication with web 2.0 tools shows the students how other students live in different countries of the world and it offers educators the opportunity to communicate effectively among themselves. These two opportunities may contribute to the importance of distance education as distance education programs are independent, individual and let the students enter the studying environments (İşman, 2008). The literature of distance education shows that there are studies about university students' perceptions or lecturers' perceptions towards distance education (Altun Ekiz, 2020; Karatepe, Küçükgençay \& Peker, 2020; Liu, Liu \& Zhong, 2020; Telli Yamamoto \& Altun, 2020), but there are limited studies about the young learners and their distance education thoughts or activities in Turkey. So, the current study pays attention to the young learners' parts of distance education in Turkey during the curfew period due to coronavirus pandemic from March to June. As Arslan, Bircan, and Eleroğlu (2019) underline the importance of students' thoughts on an issue and claim that "it is important to know what they think and feel about these environments in order to increase the efficiency of the courses offered in distance education and to enable participants to gain a positive attitude towards distance education" (p.2).

\subsection{Young learners of English}

According to United Nations Convention on the Rights of Children, the term of child generally refers to anyone who is under 18 years old as accepted in 1989. So, young learners may be at preschool education, primary or secondary schools. However, the study will mention 'young learners' as primary school students at the age of 7, 8, 9, and 10. Turkey has 12 years of compulsory education system and it consists of three parts including primary, secondary, and high schools as $4+4+4$ system. Goto Butler and Lee (2010) state that a lot of countries try to give foreign language lessons at elementary school, and Turkey has been one of these countries because teachers have started to teach English as a foreign language and English has taken as a lesson in the curricula of elementary schools for the second graders in Turkey since 2013 with a decision of MoNE.

It is obvious that the younger the learner is, the better learning and teaching a foreign language may be occur, and it is possible both in face to face education and distance education. Phillips (1993) suggests that young learners react "to language according to what it does or what they can do with it...they respond to the meaning underlying the language used and do not worry about individual words or sentences" (p.5), and she adds that young learners feel more free and enjoy the activities than older ones. Likewise, Çakır (2004) purports:

"There are of course many everyday games and puzzle activities that can be adapted to a foreign language learning situation which students will already be familiar with. Playing these games will come naturally to them and make them feel they are in a safe environment where they can venture out and take risks. Moreover, if games are used at the right moment and contain the right clues or challenges, they can provide highly considerable benefit for learners. No matter what sort or how simple it is, there is always some sort of language gain. Some language may be learned by heart as part of a fun activity without the children even being aware of it" (p.108).

In addition, Çakır (2004) presents some kinds of preferred games and activities for young learners of English such as word games, hangman, puzzles, info-gap crosswords, the same or different. Young learners of English have a lot of choices when they want to improve their English 
Canl, Z, Canl1, B. (2020). Distance education and young learners of English during curfew period due to coronavirus pandemic. International Journal of Social Sciences and Education Research, 6(2), 241-251.

especially in online resources. They may spend their leisure time during pandemic curfew period to play games, to watch cartoons, to watch YouTube kids' channels in English, and to surf on the educational websites like Eba.gov.tr, Morpakampus.com or Okulistik.com.

\subsection{COVID-19}

According to the data presented by World Health Organization (WHO), COVID-19 is accepted as a worldwide disease in February, 2020. The term of COVID-19 originates from some abbreviations of the descriptions related to the disease as 'CO' comes from Corona, 'VI' from virus, 'D' from disease and '19' from the year of 2019 and it was seen for the first time in December, 2019 in China. After three months, Turkey has started to fight against COVID-19 and the governments have begun to take precautions against COVID-19 pandemic in the light of the recommendations released by WHO. Turkey has immediately taken some decisions to cope with the coronavirus pandemic results which can be faced in health system, military forces, religion affairs and education system (Demir, Günaydın \& Demir, 2020). Worldometers website presents the information about the cases of novel coronavirus in Turkey in July 10, 2020 as 209.962 affected people, 5300 deaths, and 190,390 healed people as seen in Figure 1. , and also Turkey is the $15^{\text {th }}$ one amid 215 countries fighting novel coronavirus. Therefore, Woldometers website shares the information that in the world, there are totally 12,397,927 people who are received as cases and 557,569 people died because of this pandemic and 7,227,108 people have been healed.

Figure 1. Total COVID-19 Cases in Turkey at Worldometers website, July, 2020.

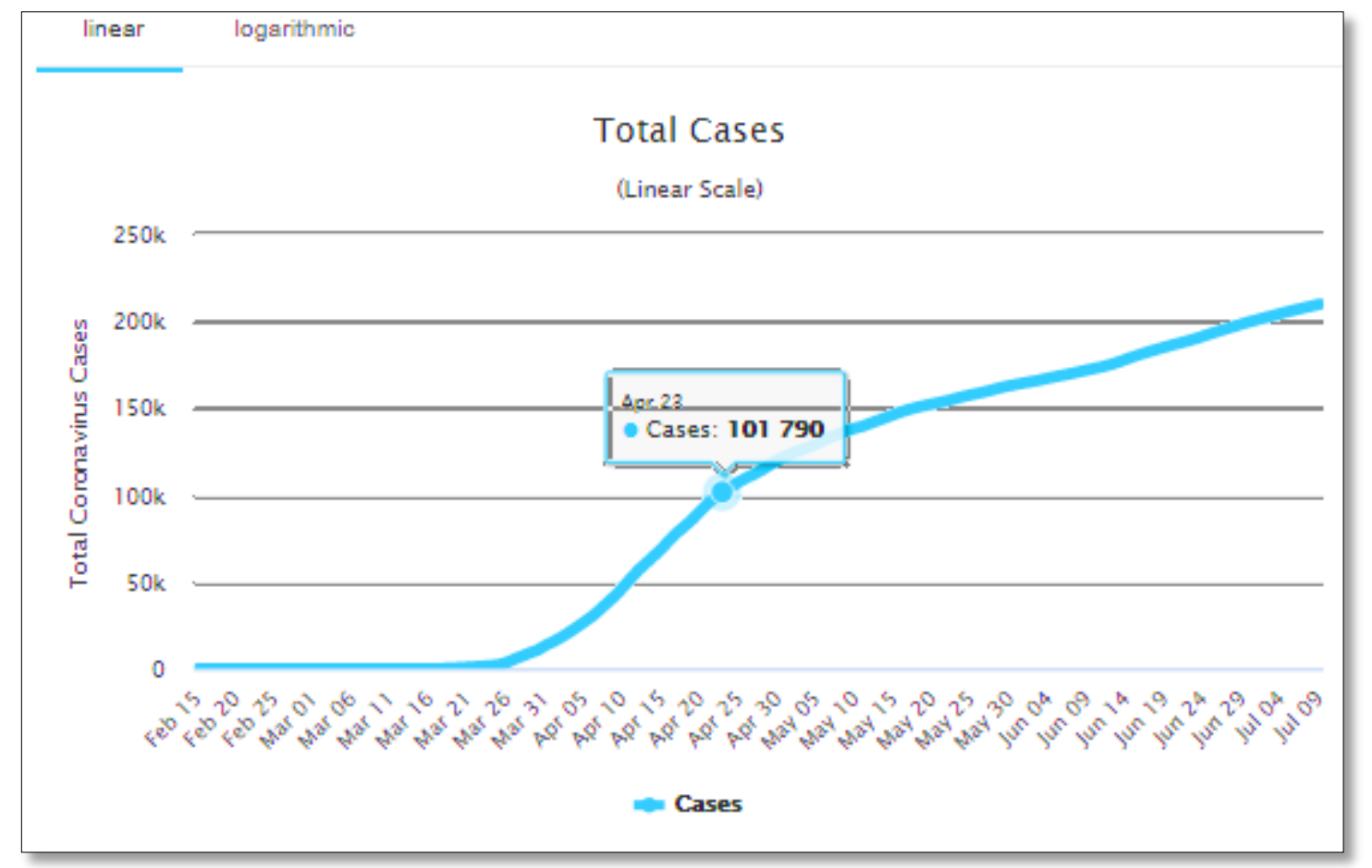

Ministry of Health of Turkey has warned the citizens to stay at home and take the preventive measures against coronavirus pandemic such as scrubbing and washing hands for at least $20 \mathrm{sec}-$ onds, wearing a mask on faces outside, covering months during coughing or sneezing and keeping social distancing. However, the number of people infected with the disease is increasing and it shows that people need to continue to be careful. Fahrettin Koca, the Turkish Minister of Health, commented about the future of COVID-19 pandemic and contributed that "the disease does not 
Canl1, Z., Canl1, B. (2020). Distance education and young learners of English during curfew period due to coronavirus pandemic. International Journal of Social Sciences and Education Research, 6(2), 241-251.

seem like it is going to be off the agenda. And it is also not possible for us to allow the disease to take a control over our lives. The best way is to find a common solution by taking some measures about our daily lives. This is the new criterion for success."

Correspondingly, Council of Higher Education in Turkey has decided to stop face to face education in the midst of March, 2020. After one week later, Ministry of National Education (MoNE) of Turkey has started to give lessons through EBA TV channels for every students at different grades of education system. In April, the curfew for children started because persons below 20 need to stay at home to prevent themselves from COVID-19 for two months. Minister of National Education, Ziya Selçuk added that "we started online teaching programs and distance education for basic education and secondary school students from three national television stations and online education platforms in cooperation with the TRT'. Therefore, schools at Ministry of National Education has started to launch distance education instead of face to face education as universities has taken the same decision for the second term of the academic year of 2019-2020 to be able to decrease the effects of the COVID-19 pandemic on students, teachers, managers, school janitors and security guards. Likewise, Ziya Selçuk stressed the importance and value of distance education as follows:

"Our online education platform is rich as it includes thousands of teaching materials. It is safe; our teachers and students enter the system by using their own accounts. It is effective; teachers can follow the attendance of their students and give live lectures. It is dynamic; teachers can upload education videos and interactive teaching materials, give assignments and follow the participation of their students in activities".

To use and attend lessons online, MoNE has given the students, parents, and teachers 8 GB free usage of internet monthly during distance education process. These arrangements in education system shows that even a small virus may be a serious reason to change everything in daily lives and its importance is required to be considered (Temel \& Ertin, 2020). Because there is no certain solution to the coronavirus disease and there is an increase of the number of the affected cases and deaths, human particularly children may be influenced emotionally, psychologically, and sociologically (Liu, Liu \& Zhong, 2020). Hereafter, COVID-19 may cause some bad effects among children namely young learners such as studying regularly, being focused in lessons, being in a blue mood, feeling bored because of staying at home all day long.

Consequently, the period of curfew due to COVID-19 pandemic has definitely influenced and made the young learners do some changes in their learning habits. To this end, the study aims to investigate the current thoughts of young learners of English about distance education and their preferences while choosing activities to improve their English during the curfew due to COVID19. Therefore, the study aims to find answers to following research questions:

1. What are the online resources and materials do young learners of English use during the curfew period due to COVID-19 pandemic?

2. What kind of education do young learners of English prefer; face to face education or distance education? Why? 
Canl, Z, Canl1, B. (2020). Distance education and young learners of English during curfew period due to coronavirus pandemic. International Journal of Social Sciences and Education Research, 6(2), 241-251.

\section{Method}

\subsection{Participants}

The participants include 32 students who are attending different state and private schools selected for the purposeful sampling from different cities in Turkey. This kind of sampling is nonrandom ways of sampling (Robinson, 2014) and Patton (2014) also suggests that "qualitative sampling designs specify minimum samples based on expected reasonable coverage of the phenomenon given the purpose of the study and stakeholders interest" (p.314) and he adds that "purposeful sampling: selecting information-rich cases to study, cases that by their nature and substance will illuminate the inquiry question being investigated. Qualitative inquiry typically focusses in depth on relatively small samples, even single cases $(n=1)$, selected for a quite purpose" (p.264). The ages of the students range from 7 and 10 year-old. Recently, 24 of the participants have been attending private primary schools and 8 of them have been attending state primary schools. 22 students are in the first grade, 2 of them are in the second grade, one of them is in the third grade and 7 of them are in the fourth grade.

Table 1. Characteristics of participants

\begin{tabular}{llll}
\hline Participants /Gender & Age & Grade & Schools \\
\hline 16 Girls - 16 Boys & $7-10$ & $1-4$ & Private (24) - State (8) \\
\hline
\end{tabular}

\subsection{Instruments}

The researcher conducted a semi-structured interview including 12 questions, and each interview lasted for a span of 15 to 20 minutes because of the limited concentration time of the target populations. Interviews were conducted and recorded via zoom application to provide social distancing and not to threaten the participants' health. Interview questions were open ended and the participants were promoted to share their experiences, ideas, and feelings during the COVID-19 pandemic without leading them (Marshall \& Rossman, 1999).

\subsection{Procedure and data analysis}

In the study, qualitative research methods are used with the help of conducting semi-structured interviews as a data-collection tool, since it is known that qualitative research refers to an "understanding a social or human problem, based on building a complex, holistic picture, formed with words, reporting detailed views of informants" (Creswell, 1994, p. 2). The answers of the participants are transcribed and coded in detail. Tables are used to provide more appreciative comprehension and the results are interpreted overtly. To provide reliability criterion, excerpts are placed in the "Results" section of the study.

\section{Findings}

The results of the study were presented under the themes including subthemes and codes in the light of the research questions' order. According to the data analysis, codes were designed meaningfully and given with their frequency measure, and also numbers are utilized for the participants instead of their names.

1. What are the online resources and materials do young learners of English use during the curfew period due to COVID-19 pandemic? 
Canl1, Z., Canl1, B. (2020). Distance education and young learners of English during curfew period due to coronavirus pandemic. International Journal of Social Sciences and Education Research, 6(2), 241-251.

All of the participants responded to the interview questions related to the first research question in Turkish and the results were illustrated in Table 2. Two sub-themes were comprised as 'including lesson materials' and 'watching videos' under the main theme of 'using online resources'. Each sub-theme includes the examples from the participants' respondents. 20 students claimed that they entered the website of Eba.gov.tr and follow their daily lessons there and they try to struggle the difficulties caused by coronavirus pandemic on the net. 5 of them (P25, P27, P29, P30, P31) claimed that Okulistik.com was very helpful for them to spend their leisure time. 4 of them (P25, P26, P28, P31) expressed that their parents bought memberships for them from Morpakampus.com to learn English, and 6 students (P25, P26, P27, P28, P30, P31) said that they paid for using Mentalup.net and found it quite beneficial and enjoyable. 29 of the participants described that they played online games and downloaded game applications on tablets, pc and their parents' mobile phone day after day. 7 students said that they had some applications to learn English on their tablets (P1, P5, P6, P12, P20, P25, and P32).

One of the participants (P25, $4^{\text {th }}$ grader) who used online resources to learn English during the curfew due to the pandemic claimed as follows:

I was bored at first in the days we stayed at home because of the pandemic, but later thanks to my mother, I found a lot of work to do. I always loved English. I also like watching videos, so YouTube is indispensable for me. I spend at least one hour every day on YouTube. I also like to play games. We downloaded English word games to my mother's phone. I play them and even ask my mom where I can't do the activities.

Similarly, another participant (P26, $4^{\text {th }}$ grader) voiced that he utilized applications to make his day more active and finish the whole day at home on his own as he said that:

Sometimes, my mom and dad went to work at the same time. I was left alone at home. They don't normally allow me to use a phone or tablet for a long time. But I was at home all day without going out, so I spent nearly 2 or 3 hours a day on the net. I love watching TV series, so I watched them from Netflix. Yes, I cannot say that I understand all of them, but I think English is a very good language and it sounds very nice.

One of the participants (P1, $1^{\text {st }}$ grader) connoted that he enjoyed to spend his leisure time while watching videos and listening to songs as follows:

Pandemic is bad, but I like to sit at home. I love watching videos on YouTube. My favorite channel is Cocomelon. Also, the videos kids are loading. Of course, I watch in English. And playing games is my job. Fisher Price has a lot of applications. I've listened since I was a baby. If my mom lets me, I hang out on the internet all day without complaining.

The average time for internet usage varied from half an hour to 4 hours. Boys claimed that they spent much more time than girls as seen below in Table 4 .

Table 4. Average time the students spend on the internet

\begin{tabular}{ll}
\hline Participants & Average time to spend on the net \\
\hline 16 Girls & Half an hour- 1 hour \\
\hline 16 Boys & At least 1 hour- $3 / 4$ hours \\
\hline
\end{tabular}

Besides, all of the participants (P25, P26, P27, P28, P29, P30, P31) who said that they utilized Okulistik.com, Morphakampus.com, Mentalup.net were $4^{\text {th }}$ grade students. Most of participants 
Canl1, Z, Canlı, B. (2020). Distance education and young learners of English during curfew period due to coronavirus pandemic. International Journal of Social Sciences and Education Research, 6(2), 241-251.

(18 students) who claimed that they generally used Eba.gov.tr to follow their English lessons were in the first grade.

Additionally, 30 of the participants expressed that they watched YouTube Channels in English including films, cartoons, daily videos, songs, or rhymes. 2 of the participants claimed that they watched Netflix on the net and they tried to improve their English. These two students were fourth grade students. One of the participants exclaimed that he watched Dailymotion, and another one claimed that he used Voscreen application to watch videos in English, these two participants were $4^{\text {th }}$ grader students, too.

Table 2. Online activities which young learners of English prefer to do during covid-19 curfew period

\begin{tabular}{|c|c|c|c|}
\hline Theme & Sub-theme & Codes & $\mathrm{f}$ \\
\hline \multirow{10}{*}{ Using Online Recourses } & \multirow{6}{*}{$\begin{array}{l}\text { Including Lesson Ma- } \\
\text { terials }\end{array}$} & Eba.gov.tr & 20 \\
\hline & & Okulistik.com & 5 \\
\hline & & Morphakampus.com & 4 \\
\hline & & Mentalup.net & 6 \\
\hline & & Game Applications & 29 \\
\hline & & Applications to learn English & 7 \\
\hline & \multirow{4}{*}{ Watching Videos } & YouTube channels & 30 \\
\hline & & Netflix.com & 2 \\
\hline & & Dailymotion.com & 1 \\
\hline & & Voscreen Application & 1 \\
\hline
\end{tabular}

2. What kind of education do young learners prefer; face to face education or distance education? Why?

All of the participants answered the related interview questions to respond the second research question of the study. As it is seen in the Table 3., 30 participants claimed that they preferred to learn and continue their education with face to face education instead of distance education.

Table 3. Types of education which young learners prefer

\begin{tabular}{ll}
\hline Participants & Types of preferred education \\
\hline 30 students (16 Girls - 13 Boys) & Face to face education \\
\hline 2 students (2 boys) & Distance education \\
\hline
\end{tabular}

One of the participants $\left(\mathrm{P} 14,1^{\text {st }}\right.$ grader $)$ uttered his feelings about the type of education he preferred as follows:

It's nice to be with my family at home, but I miss my school, my teachers, and my friends. I think face to face education is better. I wish everything would be okay, that COVID would disappear and we would return to our school immediately.

Similarly, another student (P32, $3^{\text {rd }}$ grader) expressed her thoughts about the face to face education and her experiences during distance education because of the curfew due to COVID-19 pandemic with a shaky voice as she said that:

I did not have any problems in distance education. But the pandemic scared us all. I want to play games with my friends as before we did at school. I want to learn in the class with my teachers. Face to face education is the best. I think distance education can be sometimes boring. We cannot make breaks with our friends. We can't ask almost everything for our 
Canl, Z., Canl1, B. (2020). Distance education and young learners of English during curfew period due to coronavirus pandemic. International Journal of Social Sciences and Education Research, 6(2), 241-251.

teacher. Yes there are pros, but distance education is enough for now. I missed my school so much. COVID, Pandemic... that's why I hate it the most.

Two of the participants (P11, P17, $1^{\text {st }}$ graders) expressed that they wanted to continue their education with distance education and they added:

P11: "I didn't like to wake up early anyway. I got rid of going to school early. I think distance education is for me."

P17: "They were not playing with me already at school so it was good. The children in the site are better than those in the school. I'm fine like this. Don't disturb me. Let's continue like this."

The two of the participants who preferred to distance education were in the first grade and they presented their reasons to support their ideas as seen in their excerpts above.

\section{Discussion and conclusion}

The study aimed to investigate online resources and materials which young learners of English use during the curfew period due to the COVID-19 pandemic and what kind of education young learners of English prefer; face to face education or distance education and to find out their reasons for their choices. The data presented by the study may put a brick on the wall in the studies about the young learners' preferences, and perceptions towards their education system. In the respondents of $1^{\text {st }} \mathrm{RQ}$, it was existed that nearly all of the participants tried to use online resources and materials to make their knowledge stay active during the difficult days at home because of COVID-19 pandemic. They expressed various resources and some of them claimed that they had memberships on specific websites. It may be caused from that their parents may be more interested in their children's education and they may want their students to value their leisure time at home by studying English, and they may be aware of the risk that the children can be influenced emotionally from the news about COVID-19 pandemic (Kanbur \& Akgüt, 2020). Therefore, it may be assumed that some parents have tried to decrease the risk of COVID-19 pandemic's bad effects on the children by paying for educational memberships and applications for them to entertain.

The participants who watched videos on Netflix, Dailymotion and Voscreen were $4^{\text {th }}$ graders, it may be said that the elder students are, the more various websites and application they use to learn a foreign language. It may stem from that they are accustomed to use the internet more than younger ones. The time span of the internet use is the lowest among $4^{\text {th }}$ graders, too. The reason why $4^{\text {th }}$ graders use the net less than younger ones may be that they are more conscious while using the net and they can have self-control and restrict the time on the net. This finding is also consistent with the data given by Oblinger and Oblinger (2005) as they said that information technology time let the age of learning the use of computers decrease between the ages of 5 and 8 , and by the time children tend to be more expert while using computers and benefiting from them.

Also, the results of the first research question show that websites like Eba.gov.tr, Okulistik.com, Morphakampus.com, and Mentalup.net may present more formal lessons in English while YouTube channels and applications may be more enjoyable and may contain more daily life's instantiations for the students. This finding is consistent with the results of the Imaniah, Dewi and Zakky's (2020) study as they express that watching YouTube is an attractive communication tool for children and it is obvious that it has positive effects on learning English especially 
Canl1, Z, Canl1, B. (2020). Distance education and young learners of English during curfew period due to coronavirus pandemic. International Journal of Social Sciences and Education Research, 6(2), 241-251.

improving listening skill and enriching vocabulary knowledge as a result of spending long hours on it.

In the respondents of $2^{\text {nd }} \mathrm{RQ}$, all of the participants stated that they have done some activities less or more to be active during distance education, but contrariwise, most of them preferred to learn and continue their education life in schools with face to face education. These findings are consistent with the data Çakır (2004) presented in his study, because young learners tend to do activities together and spend time with their classmates. This finding is very surprising since almost all of the participants have shown the clues that they have adapted themselves into the changes through distance education. Even though they have valued the days at the curfew period with learning and continuing the improving their English skills and they don't have any problem with distance education, 30 of them said that they did not prefer the distance education. As Gökbulut (2020) claims in his study, distance education provides the students an academic or transformative learning, but when the subjects are children, their need for social interaction needs to be considered.

Also, another finding from the study is that two participants expressed that they preferred to continue with distance education, and they were first grade students. From their excerpts, it may be assumed that they may have some other reasons for their choices such as disability in the time management, sleep disorder or school bullying. The parents, teachers and school managers are required to be more alarmed to overcome these problems immediately, and they may need to do meetings regularly to see the changes in the students' moods and emotions.

Conclusively, almost all of the participants make effort to discover various ways to be up to the bad effects of pandemic while staying at home, and the main aim of the study was to investigate the topic to present and provide knowledge for parents, teachers and authorities with a "screenshot" to assist and encourage students' participation into activities while learning a foreign language during a difficult situation as COVID-19 pandemic curfew.

\section{References}

Altun Ekiz,M.(2020). Beden Eğitimi ve Spor Yüksekokulu Öğrencilerinin Karantina Dönemindeki Uzaktan Eğitim İle İlgili Görüşleri (Nitel Bir Araştırma). Spor ve Rekreasyon Araşstırmaları Dergisi, 2(ÖS1), $1-13$.

Arslan, R., Bircan, H. \& Eroğlu H. (2019) Cumhuriyet Üniversitesi'nde Uzaktan Eğitimde Sunulan Derslere Yönelik Tutum Ölçeğinin Geliştirilmesi. Cumhuriyet Üniversitesi İktisadi ve İdari Bilimler Dergisi, 20(2), 409-427.

Cakir, I. (2004). Designing activities for young learners in EFL classrooms. Gazi Üniversitesi Gazi Eğitim Fakültesi Dergisi, 24(3).

Cresswell, J. W. (1994). Research design qualitative and quantitative approaches. Sage Publications.

Demir, M., Günaydın, Y., \& Demir, Ş. Ş. (2020). Koronavirüs (Covid-19) salgınının Türkiye'de turizm üzerindeki öncülleri, etkileri ve sonuçlarının değerlendirilmesi1. International Journal of Social Sciences and Education Research, 6(1), 80-107.

Goto Butler, Y., \& Lee, J. (2010). The effects of self-assessment among young learners of English. Language Testing, 27(1), 5-31.

Gökbulut, B. (2020). Distance Education Students' Opinions on Distance Education. In Enriching Teaching and Learning Environments With Contemporary Technologies (pp. 138-152). IGI Global. 
Canl, Z., Canl1, B. (2020). Distance education and young learners of English during curfew period due to coronavirus pandemic. International Journal of Social Sciences and Education Research, 6(2), 241-251.

Imaniah, I., Dewi, N. F. K., \& Zakky, A. (2020). Youtube Kids Channels in Developing Young Children's Communication Skills in English: Parents' beliefs, Attitudes, and Behaviors. Ijlecr-International Journal of Language Education and Culture Review, 6(1), 20-30.

İşman, A. (2008). Uzaktan eğitim. Pegem Akademi.

Kanbur, N., \& Akgül, S. (2020). Quaranteenagers: A Single Country Pandemic Curfew Targeting Adolescents in Turkey. The Journal of Adolescent Health.

Karatepe, F., Küçükgençay, N. \& Peker, B. (2020). Öğretmen adayları senkron uzaktan eğitime nasıl bakıyor? Bir anket çalışması. Journal of Social and Humanities Sciences Research, 7(53), 1262-1274.

Kaya, Z. (2002). Uzaktan eğitim. Pegem A Yayıncılık.

Liu, X., Liu, J., \& Zhong, X. (2020). Psychological State of College Students During COVID-19 Epidemic. SSRN Electronic Journal. https://doi.org/10.2139/ssrn.3552814.

Ministry of Health of Turkey (2020). "We Have to Be among the Heroes to Save Lives by Preventing Transmission". https://www.saglik.gov.tr/EN,66546/quotwe-have-to-be-among-the-heroes-to-savelives-by-preventing-transmissionquot.html

MoNE (2020). Ministry of National Education of Turkey. Minister Selçuk Talks about Turkey's Covid-19 Experience to G20 Countries http://www.meb.gov.tr/minister-selcuk-talks-about-turkeys-covid-19-experience-to-g20-countries/haber/21202/en

Patton, M. Q. (2014). Qualitative research \& evaluation methods: Integrating theory and practice. Sage publications.

Phillips, S. (1993). Young learners. Oxford University Press.

Oblinger, D., \& Oblinger, J. (2005). Is it age or IT: First steps toward understanding the net generation. Educating the net generation, 2(1-2), 20.

Oliver C. Robinson (2014) Sampling in Interview-Based Qualitative Research: A Theoretical and Practical Guide, Qualitative Research in Psychology, 11:1, 25-41, DOI: 10.1080/14780887.2013.801543

Telli, S. G., \& Altun, D. (2020). Coronavirüs ve çevrimiçi (online) eğitimin önlenemeyen yükselişi. Üniversite Araştırmaları Dergisi, 3(1), 25-34.

Tutku, E., Ilıman, E., \& Dönmez, E. (2020). Bireylerin Sağlik Anksiyetesi Düzeyleri İle Covid-19 Salgini Kontrol Algisinin Karşilaştirilmasi. Uluslararası Sağllk Yönetimi ve Stratejileri Araştırma Dergisi, 6(1), 139-154.

Uşun, S.(2006). Uzaktan Eğitim. Nobel Yayın Dağıtım

WHO (2020). Coronavirus disease (COVID-19) advice for the public. https:/www.who.int/emergencies/diseases/novel-coronavirus-2019/advice-for-public

www.worldometers.info/coronavirus/country/turkey/ 